\title{
PENGEMBANGAN PERANGKAT PEMBELAJARAN BERORIENTASI PENDEKATAN GUIDED DISCOVERY UNTUK MELATIHKAN KETERAMPILAN BERPIKIR KRITIS DAN KREATIF
}

\author{
Anna Roosyanti \\ Program Studi PGSD, Fakultas Bahasa dan Sains, Universitas Wijaya Kusuma \\ a.roosyanti@gmail.com
}

\begin{abstract}
Abstrak
Penelitian ini bertujuan untuk menghasilkan perangkat pembelajaran berorientasi Guided Discovery untuk melatihkan keterampilan berpikir kritis dan kreatif. Dilaksanakan dalam dua tahap yaitu pengembangan dengan model 4-P (4-D Models) dan diujicoba pada 30 siswa kelas VII SMP Mujahidin Surabaya, dengan rancangan one group pretest-posttest design. Data dianalisis secara deskriptif kuantitatif dan kualitatif. Hasil penelitian menunjukkan bahwa perangkat pembelajaran valid dan baik, keterampilan berpikir kritis dan kreatif meningkat. Hasil validasi RPP 3,87, LKS 3,87 , buku siswa 3,59, tes hasil belajar 3,87, tes keterampilan berpikir kritis 3,64 dan lembar penilaian keterampilan berpikir kritis dan kreatif sebesar 3,63. Ketuntasan hasil belajar siswa meningkat dengan rata-rata proporsi jawaban sebesar 80,70\%. Ketuntasan klasikal sebesar $80 \%$. Simpulan penelitian bahwa perangkat pembelajaran berorientasi Guided Discovery yang dikembangkan dapat meningkatkan keterampilan berpikir kritis dan kreatif siswa, serta dapat meningkatkan ketuntasaan hasil belajar siswa.
\end{abstract}

Kata kunci: Keterampilan Berpikir Kreatif, Keterampilan Berpikir Kritis, Penemuan Terbimbing (Guided Discovery).

\begin{abstract}
This research aims to develop Guided Discovery based teaching learning package to facilitate the critical and creative thinking skills. These teaching learning package were implemented in two phases, namely the development of the model 4-P (4-D Models) and the implementation on 30 students of VII grade of Mujahidin Junior High School of Surabaya, using one group pretestposttest design. Data was analyzed descriptively quantitative and qualitative. The results showed that Guided Discovery based teaching learning package valid and good, critical and creative thinking skills increased. Validation result are for RPP 3.87, LKS 3.87, students book 3.59, learning outcomes test 3.87, critical thinking skills test 3.64, thinking critical and creative skills assessment form 3.63. The students mastery of learning outcomes was with proportion of 80,70\%. Based on the data it can be concluded that the Guided Discovery based teaching learning package can improve students critical and creative thinking skills, and to improve students mastery of learning outcomes.
\end{abstract}

Keywords: Creative Thinking Skills, Critical Thinking Skills, Guided Discovery. 


\section{Pendahuluan}

Seiring dengan berkembangnya zaman, teknologi dan informasi akan serta merta mengalami perkembangan dengan sangat pesat. Kita dituntut untuk dapat terus berpacu mengikuti perkembangan yang terjadi. Salah satu faktor yang tidak dapat dilepaskan seiring dengan perkembangan zaman yaitu media, baik media cetak maupun media elektronik terutama dengan berkembangnya teknologi informasi dan komunikasi. Akibat terlalu banyaknya informasi dibandingkan dengan alokasi waktu yang tersedia untuk pembelajaran, maka guru tidak mampu mengajarkan semua informasi tersebut kepada siswa. Jika hal ini dipaksakan, maka penyajian informasi tersebut menjadi tidak bermakna. Peserta didik menjadi tidak mampu menerapkan apa yang telah dipelajarinya di sekolah untuk memecahkan masalah yang ada di sekitar mereka, oleh karena itu agar siswa mampu mengikuti perkembangan informasi mereka harus dibekali dengan kemampuan untuk berpikir kritis sehingga mampu menemukan sendiri informasi yang diperlukan. Siswa harus dibekali dengan seperangkat "alat" yang dapat membantu mereka dalam memecahkan masalah yang dihadapi untuk kemudian menemukan informasi yang diperlukan serta mampu melakukan seleksi secara kritis informasi mana yang diperlukan dan informasi mana yang tidak diperlukan.

Menurut Ibrahim (2008), kondisi pembelajaran sekarang yang masih banyak kita jumpai masih berlandaskan pada teacher centered. Prinsip ini yang seharusnya segera kita ubah menjadi student centered yang mengorientasikan siswa kepada situasi yang bermakna, kontekstual, dunia nyata dan menyediakan sumber belajar, bimbingan, petunjuk bagi pebelajar ketika mereka mengembangkan pengetahuan tentang materi pelajaran yang dipelajarinya sekaligus keterampilan memecahkan masalah.

Keterampilan berpikir kritis merupakan salah satu modal dasar atau modal intelektual yang sangat penting bagi setiap orang dan merupakan bagian fundamental dan kematangan manusia yang harus dilatihkan seiring dengan pertumbuhan intelektual seseorang (Ibrahim, 2008), bahkan menurut Gagne (1985) kemampuan pemecahan masalah merupakan hasil belajar yang paling tinggi. Untuk dapat melakukan dan memiliki kemampuan berpikir kritis, siswa harus dilatih melakukan proses belajar seperti para Ilmuwan belajar dan menemukan informasi di alam. Berdasarkan penelitian Redhana (2009), bahwa sebagian guru-guru belum memahami hakekat dari pembelajaran keterampilan berpikir kritis, sangat sedikit indikator keterampilan berpikir kritis yang muncul dalam indikator hasil belajar. Keterampilan berpikir mirip dengan keterampilan prosedural, yakni keterampilan-keterampilan ini bebas konteks. Saat siswa belajar merencanakan, menyimpulkan atau menggeneralisasikan, atau menggunakan keterampilan berpikir lainnya, siswa pada akhirnya akan dapat menggunakan keterampilan-keterampilan berpikir ini dalam berbagai situasi termasuk dalam konteks kehidupan sehari-hari. Inilah yang membuat keterampilan berpikir itu begitu penting (Eggen and Kauchak, 1996).

Berpikir kritis merupakan salah satu proses berpikir kompleks di bawah berpikir kreatif. Dalam proses berpikir kritis, seseorang memusatkan perhatian pada analisis terhadap suatu hal (Setiawan, 2005). Menurut Krulik and 
Rudnick (1996) dalam proses berpikir kreatif, seseorang memproduksi hasil kompleks, inventif, mampu mensintesis, menggeneralisasikan dan menggunakan ide.

Azumardi dalam Suryosubroto (2009) menyatakan bahwa paradigma pendidikan harus dilandasi sistem pembelajaran yang mengajarkan berpikir kritis dan kreatif. Berpikir kritis merupakan penilaian kritis terhadap kebenaran fenomena, sedangkan berpikir kreatif berkaitan dengan kemampuan untuk memaknai fenomena. Keterampilan berpikir kritis memfokuskan pada proses belajar daripada hanya pemerolehan pengetahuan. Keterampilan berpikir kritis sangat penting dalam proses belajar mengajar karena keterampilan ini memberikan kesempatan kepada siswa belajar melalui penemuan.

Menurut Munandar (2009) bahwa salah satu kendala terhadap "gerakan kreativitas" terletak pada alat-alat ukur (tes) yang biasanya dipakai di sekolahsekolah, yaitu tes inteligensi tradisional yang mengukur kemampuaan siswa untuk belajar, dan tes prestasi belajar untuk menilai kemajuan siswa selama program pendidikan. Baik tes inteligensi maupun tes prestasi belajar kebanyakan hanya meliputi tugas-tugas yang harus dicari satu jawaban yang benar (berpikir konvergen). Kemampuan berpikir divergen dan kreatif, yaitu menjajaki berbagai kemungkinan jawaban atas suatu masalah, jarang diukur.

Discovery adalah suatu proses mental, dimana anak atau individu mengasimilasi konsep dan prinsipprinsip (Carin, 1993). Discovery learning adalah suatu proses pembelajaran yang muncul ketika siswa dengan bimbingan guru dapat meningkatkan kemampuan kognitif, psikomotor dan afektif melalui eksperimen secara langsung (Abruscato,
1992). Arend (2007) mengemukakan bahwa Discovery Learning menekankan pada pengalaman belajar aktif yang berpusat pada siswa, siswa menemukan ide-idenya sendiri dan mengambil maknanya sendiri. Hal tersebut didukung oleh Karim (2011) yang mengemukakan bahwa pemahaman konsep dan kemampuan berpikir kritis siswa dengan metode penemuan terbimbing lebih baik dari pada siswa yang mengikuti pembelajaran konvensional.

Pengamatan di lapangan dari berbagai hasil penelitian menyebutkan bahwa pembelajaran dengan pendekatan Discovery Learning untuk mengajarkan keterampilan berpikir kritis dan kreatif semacam itu kurang bahkan belum dilatihkan, sedangkan di negara-negara maju kemampuan berpikir kritis telah lama dikembangkan dan dijadikan dasar untuk meningkatkan mutu pendidikan Sains. Salah satu penyebabnya yaitu kurang tersedianya perangkat pembelajaran yang relevan yang dapat dijadikan acuan guru dalam menerapakan keterampilan berpikir kritis, bahkan menurut penelitian Nur, dkk (2002) ditemukan bahwa kebutuhan sekolah diantaranya adalah materi tercetak yang berorientasi pada pendekatan keterampilan proses. Rustaman (2002) menjelaskan bahwa minimnya perangkat soal yang mengukur pencapaian hasil belajar sains dalam hal berpikir menjadi salah satu penyebab kurang diberdayakannya pengembangan proses berpikir dalam pendidikan sains. Hal tersebut tentunya tidak sejalan dengan UU No 20 Tahun 2003 Tentang Sistem Pendidikan Nasional pada Pasal 3 , yang menyebutkan bahwa pendidikan nasional berfungsi mengembangkan kemampuan dan membentuk karakter serta peradaban bangsa yang bermartabat dalam rangka mencerdaskan kehidupan bangsa. Pendidikan nasional bertujuan 
untuk berkembangnya potensi peserta didik agar menjadi manusia yang beriman dan bertakwa kepada Tuhan Yang Maha Esa, berakhlak mulia, sehat, berilmu, cakap, kreatif, mandiri, dan menjadi warga negara yang demokratis serta bertanggung jawab.

Pembelajaran IPA bukanlah sekedar serangkaian kompetensi dasar, tetapi juga dapat diterapkan dan bermanfaat bagi kehidupannya seharihari. Hal tersebut sejalan dengan 9 pilar karakter mulia, yakni (1) cinta Tuhan dan kebenaran; (2) tanggung jawab, kedisiplinan, dan kemandirian; amanah; (4) hormat dan santun; (5) kasih sayang, kepedulian, dan kerjasama; (6) percaya diri, kreatif, dan pantang menyerah, (7) keadilan dan kepemimpinan, (8) baik dan rendah hati; dan (9) toleransi dan cinta damai.

Berdasarkan latar belakang masalah yang telah dikemukakan di atas, maka tujuan penelitian ini yaitu mengembangkan perangkat pembelajaran berorientasi Guided Discovery yang valid, praktis, efektif, dan dapat meningkatkan keterampilan berpikir kritis dan kreatif, serta mencapai ketuntasan hasil belajar siswa.

\section{Metode Penelitian}

Penelitian ini termasuk penelitian pengembangan, dengan menggunakan pendekatan model 4-D (Four D Models). Mengembangkan perangkat pembelajaran menggunakan pendekatan Penemuan Terbimbing (Guided Discovery) untuk melatihkan keterampilan berpikir kritis dan kreatif.

Subyek penelitian adalah perangkat pembelajaran dengan menggunakan pendekatan Penemuan Terbimbing (Guided Discovery) untuk melatihkan keterampilan berpikir kritis dan kreatif. Perangkat pembelajaran yang dikembangkan terdiri dari Rencana Pelaksanaan Pembelajaran (RPP), Lembar Kegiatan Siswa (LKS), Materi, Buku Siswa, dan Tes Hasil Belajar Kognitif, Tes Keterampilan Berpikir Kritis dan Kreatif, Lembar Penilaian Keterampilan Berpikir Kritis dan Kreatif. Uji coba dilaksanakan di kelas VII SMP Mujahidin Surabaya.

Kegiatan ini ditujukan untuk menilai keterlaksanaan perangkat pembelajaran dengan menggunakan pendekatan Penemuan Terbimbing (Guided Discovery), termasuk keterampilan berpikir kritis dan kreatif yang dikembangkan. Pelaksanaan uji coba ini mengimplementasikan rancangan "One-Group Pretest-Posttest Design" yang dikembangkan oleh Campbell dan Stanley (Arikunto, 2006), dengan pola sebagai berikut:

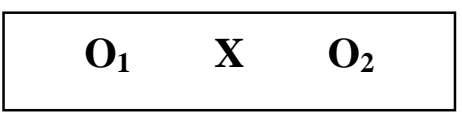

Keterangan:

$$
\begin{array}{rlr}
\mathrm{O}_{1}= & \text { Uji awal (pretest) untuk mengetahui } \\
& \text { penguasaan awal siswa terhadap } \\
& \text { materi sebelum diberikan perlakuan. } \\
\mathrm{O}_{2}= & \text { Uji akhir } \text { (posttest), untuk } \\
& \text { mengetahui penguasaan } & \text { siswa } \\
& \text { terhadap materi setelah diberi } \\
\mathrm{X}= & \text { perlakuan. } & \\
& \text { Perlakuan, yaitu pelaksanaan } \\
& \text { pembelajaran dengan menerapkan } \\
& \text { perangkat pembelajaran yang } \\
& \text { dikembangkan } & \text { (Perangkat } \\
& \text { pembelajaran } & \text { berorientasi } \\
& \text { pendekatan Penemuan Terbimbing } \\
& \text { (Guided Discovery) r untuk } \\
& \text { mengajarkan keterampilan berpikir } \\
& \text { kritis dan kreatif). }
\end{array}
$$

Berdasarkan rumusan masalah penelitian, variabel dalam penelitian ini meliputi: Pertama, Pengukuran kualitas perangkat pembelajaran, terdiri dari (a) 
Validitas perangkat pembelajaran; (b) Tingkat keterbacaan LKS dan Buku Siswa dan (c) Tingkat kesulitan LKS dan Buku Siswa. Kedua, pengukuran kepraktisan perangkat pembelajaran, macamnya: (a) Keterlaksanaan RPP dan (b) Hambatan-hambatan selama pembelajaran.

Ketiga, pengukuran ffektivitas perangkat pembelajaran yang dikembangkan terhadap hasil belajar siswa yang ditinjau dari beberapa aspek, antara lain: (a) Ketuntasan hasil belajar siswa; (b) Keterampilan berpikir kritis; (c) Keterampilan berpikir kreatif; dan (d) Respon siswa.

Proses pengumpulan data untuk menentukan kelayakan perangkat pembelajaran yang dikembangkan, melalui 2 tahap, yang pertama yaitu memvalidasi perangkat pembelajaran yang telah dikembangkan dan tahap yang kedua dengan pengumpulan data pada uji coba 1 dan 2 yang bertujuan untuk menilai implementasi perangkat pembelajaran yang dikembangkan, dengan menggunakan teknik observasi, pemberian tes, dan angket.

Hasil belajar siswa dikatakan telah tuntas apabila menguasai $75 \%$ tujuan pembelajaran yang harus dicapai. Analisis yang digunakan yaitu deskriptif kuantitatif dan kualitatif. Perhitungan ketuntasan hasil belajar siswa pada masing-masing aspek dihitung menggunakan rumus:

Ketuntasan Individu $=\frac{\text { fumian skor y dug a jperoleh }}{\text { skor makstmum }} \times 100$

Ketuntasan tujuan pembelajaran dihitung dengan menggunakan rumus:

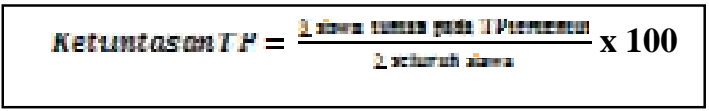

Tujuan pembelajaran dikatakan tuntas apabila $\geq 75 \%$ siswa mencapai tujuan pembelajaran. Hasil Tes Hasil Belajar Kognitif siswa juga dianalisis secara deskriptif kuantitatif dan kualitatif, yaitu dengan analisis N-Gain dan analisis Sensitivitas butir soal. Gain menunjukkan perbedaan penguasaan atau pemahaman konsep siswa sebelum dan setelah diberikan perlakuan. Gain skor ternormalisasi menunjukkan tingkat efektivitas perlakuan daripada perolehan skor. N-Gain dirumuskan oleh Hake (1999:1) sebagai berikut

$\%<\mathrm{g}>=\left(\%<\mathrm{S}_{\mathrm{f}}-\mathrm{S}_{\mathrm{i}}>\right) /\left(100-\%<\mathrm{S}_{\mathrm{i}}>\right)$

Keterangan:

$\langle\mathrm{g}\rangle=$ indeks gain $(\mathrm{N}-$ Gain $)$

$\left\langle\mathrm{S}_{\mathrm{i}}\right\rangle=$ perolehan skor sebelum perlakuan (pretest)

$\left\langle\mathrm{S}_{\mathrm{f}}\right\rangle=$ perolehan skor setelah perlakuan (posttest)

Kriteria N-Gain menurut Hake (1999) terbagi atas 3 tingkatan yakni:

1) Pembelajaran dengan "gain-tinggi", jika $\langle\mathrm{g}\rangle \geq 0,7$;

2) Pembelajaran dengan "gain-sedang", jika 0,7$\rangle\langle\mathrm{g}\rangle \geq 0,3$; dan

3) Pembelajaran dengan "gain-rendah", jika $\langle$ g $><0,3$.

Untuk mengetahui kepekaan terhadap suatu pembelajaran perlu dicari sensitivitas butir soal. Analisis sensitivitas ini dilakukan pada Tes Hasil Belajar Kognitif. Indeks sensitivitas dari suatu butir soal menunjukkan ukuran seberapa baik butir soal dapat membedakan antara siswa yang telah menerima pembelajaran dengan yang belum menerima pembelajaran. Indeks butir yang efektif terdapat antara 0,00 dan 1,00 dan nilai positif yang semakin besar menunjukkan bahwa kepekaan butir soal terhadap efek-efek pembelajaran juga semakin besar, sedangkan kriteria yang dipakai untuk menyatakan bahwa setiap butir peka atau sensitif terhadap efek-efek pembelajaran 
adalah mempunyai nilai sensitivitas $(\mathrm{S}) \geq$ 0,30 (Purwanto, 2006: 135).

Rumus untuk menghitung sensitivitas butir soal dalam bentuk essay dapat dicari dengan persamaan berikut:

$$
\boldsymbol{S}=\frac{\boldsymbol{R}_{a}-\boldsymbol{R}_{b}}{\boldsymbol{T}}=\boldsymbol{P}_{a}-\boldsymbol{P}_{b}
$$

\section{Keterangan:}

$\mathrm{S}=$ sensitivitas butir soal

$R_{a}=$ jumlah siswa yang menjawab benar pada uji akhir $\left(\mathrm{U}_{2}\right)$

$R_{b}=$ jumlah siswa yang menjawab benar pada uji awal $\left(\mathrm{U}_{1}\right)$

$T^{\prime}=$ jumlah siswa yang mengikuti tes

$P_{a}=$ proporsi jawaban benar pada uji akhir $\left(\mathrm{U}_{2}\right)$
$P_{b}=$ proporsi jawaban benar pada uji awal $\left(\mathrm{U}_{1}\right)$

(Gronlund, 1981: 266)

Analisis terhadap keterampilan berpikir kritis siswa dapat dilakukan dengan memberikan skor pada hasil tes. Pemberian skor didasarkan pada skala Taksonomi Solo yang dikembangkan oleh (Biggs \& Collins (1982) dalam Habibi (2009)). Skor yang diperoleh pada setiap soal akan dirata-rata untuk mendapatkan hasil tingkat kemampuan berpikir kritis siswa. Analisis deskriptif kuantitatif dan kualitatif terhadap tingkat kemampuan berpikir kritis siswa didasarkan pada skala sebagai berikut:

Tabel 1. Tabel Skala Tingkat Berpikir Berdasarkan Taksonomi Solo

\begin{tabular}{|c|c|}
\hline Skala & Keterangan \\
\hline $\begin{array}{c}0 \\
\text { Prestructural }\end{array}$ & $\begin{array}{l}\text { Hanya menggunakan kemampuan berpikir dasar dan jawabannya tidak } \\
\text { termasuk kedalam permasalahan. }\end{array}$ \\
\hline $\begin{array}{c}1 \\
\text { Unistructural }\end{array}$ & $\begin{array}{l}\text { Jawaban dapat disimpulkan kedalam kriteria penyelesaian masalah, yaitu } \\
\text { menggunakan proses-proses berpikir dasar untuk memilih respon terbaik dari } \\
\text { beberapa pilihan, mengumpulkan informasi yang diperlukan dalam cakupan } \\
\text { topik. }\end{array}$ \\
\hline$\stackrel{2}{2}$ & $\begin{array}{l}\text { Jawaban dapat disimpulkan kedalam kriteria pembuatan keputusan, yaitu } \\
\text { menggunakan proses-proses dasar untuk memilih respon terbaik dari beberapa } \\
\text { pilihan, mengumpulkan informasi yang diperlukan dalam cakupan topik. }\end{array}$ \\
\hline $\begin{array}{c}3 \\
\text { Relational }\end{array}$ & $\begin{array}{l}\text { Jawaban dapat disimpulkan kedalam kriteria berpikir kritis, yaitu } \\
\text { menggunakan proses-proses berpikir dasar untuk menganalisis argumen dan } \\
\text { interpretasi, mengembangkan pola-pola pembentukan alasan yang logis dan } \\
\text { mengganti asumsi-asumsi yang mendasari. }\end{array}$ \\
\hline $\begin{array}{l}4 \\
\text { Extended } \\
\text { Abstrac }\end{array}$ & $\begin{array}{l}\text { Jawaban menggunakan proses-proses berpikir dasar untuk mengembangkan } \\
\text { atau menciptakan ide-ide baru, estetis dan membangun, yang berhubungan } \\
\text { dengan persepsi sekaligus konsep }\end{array}$ \\
\hline
\end{tabular}

Sumber: Biggs \& Collins (1982) dalam Habibi (2009)

Skor yang diperoleh pada tiap soal kemudian dirata-rata untuk mendapatkan nilai tingkat keterampilan berpikir kritis siswa.

Hasil tes keterampilan berpikir kreatif siswa juga dianalisis secara deskriptif kuantitatif dan deskriptif kualitatif, yaitu dengan analisis N-Gain dan analisis sensitivitas butir soal. Selain mengunakan tes kreativitas verbal dan tes kreativitas produk, pengukuran keterampilan berpikir kreatif siswa dilakukan menggunakan skala sikap kreatif yang dikembangkan oleh Mustami (2007).

Analisis terhadap keterampilan berpikir kreatif siswa baik melalui Tes kreativitas verbal maupun Tes kreativitas produk secara deskriptif kuantitatif dan kualitatif dapat dilakukan dengan 
memberikan skor pada hasil tes kemampuan berpikir kreatif berdasarkan rubrik yang telah dikembangkan. Pemberian skor didasarkan pada Skor yang diperoleh pada setiap soal akan dirata-rata untuk mendapatkan hasil tingkat kemampuan berpikir kreatif siswa. Analisis deskriptif kualitatif terhadap tingkat kemampuan berpikir kreatif siswa didasarkan pada tabel2.

Tabel 2. Skala Tingkat Berpikir Berdasarkan Tes Kemampuan Berpikir Divergen

\begin{tabular}{|c|c|}
\hline Kriteria & Keterangan \\
\hline Keterampilan berpikir lancar & $\begin{array}{l}\text { Mencetuskan banyak gagasan, jawaban, penyelesaian masalah, pertanyaan, } \\
\text { memberikan banyak cara atau saran untuk melakukan berbagai hal serta } \\
\text { selalu memikirkan lebih dari satu jawaban. }\end{array}$ \\
\hline $\begin{array}{l}\text { Keterampilan berpikir luwes } \\
\text { atau fleksibel }\end{array}$ & $\begin{array}{l}\text { Menghasilkan gagasan, jawaban atau pertanyaan yang bervariasi, dapat } \\
\text { melihat suatu masalah dari sudut pandang yang berbeda-beda, mencari } \\
\text { banyak alternatif atau arah yang berbeda-beda, serta mampu mengubah } \\
\text { cara pendekatan atau cara pemikiran. }\end{array}$ \\
\hline $\begin{array}{l}\text { Keterampilan } \\
\text { orisinal }\end{array}$ & $\begin{array}{l}\text { Mampu melahirkan ungkapan yang baru dan unik, memikirkan cara yang } \\
\text { tidak lazim untuk mengungkapkan diri, serta mampu membuat kombinasi- } \\
\text { kombinasi yang lazim dari bagian-bagian atau unsur-unsur. }\end{array}$ \\
\hline $\begin{array}{l}\text { Keterampilan merinci atau } \\
\text { mengelaborasi }\end{array}$ & $\begin{array}{l}\text { Mampu memperkaya dan mengembangkan suatu gagasan atau produk, dan } \\
\text { menambahkan atau merinci secara detail dari suatu objek, gagasan, atau } \\
\text { situasi sehingga menjadi lebih menarik. }\end{array}$ \\
\hline Keterampilan menilai & $\begin{array}{l}\text { Menentukan patokan penilaian sendiri dan penentuan apakah suatu } \\
\text { pertanyaan benar, suatu rencana sehat, atau suatu tindakan bijaksana, } \\
\text { mampu mengambil keputusan terhadap situasi yang terbuka, serta tidak } \\
\text { hanya mencetuskan gagasan tetapi juga melaksanakannya. }\end{array}$ \\
\hline
\end{tabular}

Sumber: Guilford dalam Munandar (2009

Skala sikap kreatif terdiri dari 35 pertanyaan yang dijawab dengan 5 kriteria model Likert, yaitu sangat setuju, setuju, ragu-ragu, tidak setuju, dan sangat tidak setuju. Nilai skor kemampuan berpikir kreatif diperoleh dengan cara menjumlahkan skor-skor yang diperoleh dari setiap sub tes dengan prosedur: (a) Mendaftar semua respon atau jawaban yang diberikan oleh siswa; (b) Membuat turus (tally) dari setiap respon yang diberikan oleh siswa; (c) Menentukan skor dari setiap respon yang diberikan dengan ketentuan: skor 1 untuk reaksi positif (sangat setuju dan setuju) terhadap pertanyaan, dan skor 0 untuk reaksi negatif (sangat tidak setuju, tidak seuju, dan ragu-ragu) terhadap pertanyaan. Pertanyaan disusun secara acak. (d) Membuat tabel skor dari kemampuan berpikir kreatif untuk semua subjek penelitian. (e) Berdasarkan rata- rata ditentukan kriteria kemampuan berpikir kreatif dengan ketentuan berikut:

$$
\begin{array}{ll}
0-7 & =\text { sangat kurang } \\
8-14 & =\text { kurang } \\
15-21 & =\text { sedang } \\
22-28 & =\text { tinggi } \\
29-35 & =\text { sangat tinggi }
\end{array}
$$

\section{Hasil Penelitian dan Pembahasan}

Berdasarkan hasil analisis data, berikut ini akan diuraikan pembahasan hasil penelitian yang meliputi validitas dan hasil implementasi perangkat pembelajaran yang dikembangkan.

\section{Validitas Perangkat Pembelajaran}

RPP yang dikembangkan oleh peneliti adalah RPP untuk Kompetensi Dasar: 7.4. Mengaplikasikan peran manusia dalam pengelolaan lingkungan 
untuk mengatasi pencemaran dan kerusakan lingkungan. Validasi RPP dilakukan oleh dua orang Validator yaitu Prof. Dr. Muslimin Ibrahim, M.Pd dan Dr. sc.agr. Yuni Sri Rahayu, M.Si. Berdasarkan hasil validasi RPP diperoleh nilai rata-rata 3,87 , yang termasuk dalam kategori valid dan baik.

Aspek yang dinilai dalam validasi LKS antara lain: format, bahasa, dan isi. Penilaian dari dua orang validator yaitu Prof. Dr. Muslimin Ibrahim, M.Pd dan DR. Fida Rachmadiarti, M.Kes terhadap ketiga aspek penilaian tersebut diperoleh nilai rata-rata validasi LKS sebesar 3,87, menunjukkan bahwa LKS secara umum sudah valid dan baik, sehingga dapat digunakan dalam pembelajaran dengan revisi kecil.

Buku siswa yang digunakan pada penelitian ini dikembangkan berdasarkan kriteria pengembangan buku ajar menurut BSNP (2006). Buku siswa yang dikembangkan mencakup pokok bahasan Pencemaran dan Kerusakan Lingkungan, selanjutnya dibagi lagi menjadi beberapa sub pokok bahas.

Aspek penilaian validasi Buku Siswa meliputi: komponen kelayakan isi, komponen kebahasaan, serta komponen penyajian. Berdasarkan hasil validasi yang dilakukan oleh dua orang Validator yaitu Prof. Dr. Muslimin Ibrahim, M.Pd dan DR. Fida Rachmadiarti, M.Kes, diperoleh nilai rata-rata validasi Buku Siswa sebesar 3,59, yang berarti bahwa Buku Siswa yang telah dikembangkan dalam kategori valid dan baik, sehingga dapat digunakan dalam pembelajaran dengan revisi kecil.

Di setiap sub pokok bahasan tersebut terdapat unsur kegiatan mandiri siswa berupa berpikir kritis, berpikir kreatif, cek konsep, percobaanpercobaan sederhana, informasi tentang lingkungan, dan pertanyaan-pertanyaan yang dapat memacu rasa ingin tahu siswa. Hal tersebut bertujuan untuk menunjang proses melatihkan keterampilan berpikir kritis dan kreatif. Bagian dalam buku antara lain lab mini, cek konsep, berpikir kritis dan kreatif tidak lain adalah merupakan latihan bagi siswa untuk mencapai indikator keterampilan berpikir kritis dan kreatif. (Fogarty \& Bellanca (1986) dalam Suyanik (2010)).

\section{Validitas Tes Hasil Belajar}

Validasi Tes Hasil Belajar dilakukan oleh dua orang Validator yaitu Prof. Dr. Muslimin Ibrahim, M.Pd dan Dr. sc.agr. Yuni Sri Rahayu, M.Si. Aspek penilaian validasi meliputi: komponen kelayakan isi, komponen kebahasaan, serta komponen penyajian. Berdasarkan hasil validasi diperoleh informasi bahwa mendapat nilai rata-rata validasi sebesar 3,89, yang dapat dikatakan sangat baik, sehingga dapat digunakan dalam pembelajaran.

\section{Validitas Tes Keterampilan Berpikir Kritis dan Keterampilan Berpikir Kreatif}

Penilaian keterampilan berpikir kritis mengacu pada rubrik yang telah dikembangkan. Aspek penilaian validasi meliputi: validitas isi, bahasa dan penulisan soal. Tes keterampilan berpikir kritis yang telah dikembangkan mendapat nilai rata-rata validasi sebesar 3,64. Yang berarti dalam kategori sangat valid dan baik, sehingga dapat diterapkan dalam pembelajaran dengan revisi kecil.

Tes keterampilan berpikir kreatif yang berupa Tes Kreativitas Verbal yang dikembangkan tidak diuji validitasnya. Hal tersebut dikarenakan tes ini dikembangkan dengan mengadaptasi Tes Kreativitas Verbal yang dikembangkan oleh Munandar (2009), jadi tes tersebut sudah valid. Tes keterampilan berpikir kreatif diberikan 
dalam dua bentuk, yaitu Tes Kreativitas Verbal dan Tes Kreativitas Produk. Tes Kreativitas Produk yang telah dikembangkan secara umum dalam kategori sangat valid dan baik, sehingga dapat diterapkan dalam pembelajaran dengan revisi kecil.

\section{Validitas Lembar Penilaian Keterampilan Berpikir Kritis dan Kreatif}

Aspek penilaian validasi meliputi: format, isi, dan bahasa. Berdasarkan hasil validasi didapatkan nilai rata-rata validasi sebesar 3,63, sehingga dapat disimpulkan bahwa lembar penilaian keterampilan berpikir kritis ini secara umum valid dan sangat baik, sehingga sangat layak apabila digunakan dalam pembelajaran.

Lembar Penilaian Keterampilan Berpikir Kreatif berupa Tes Kreativitas Verbal dan Tes Kreativitas Produk. Instrumen tersebut dinilai dengan menggunakan lembar penilaian keterampilan berpikir kreatif (Tes Kreativitas Produk beserta rubriknya). Selain menggunakan instrumen Tes kreativitas verbal dan Tes kreativitas produk, penilaian keterampilan berpikir kreatif siswa diukur menggunakan skala sikap kreatif yang dikembangkan oleh Mustami (2007). Skala sikap kreatif tidak diuji validitasnya karena mengacu pada skala sikap kreatif yang dikembangkan oleh Mustami (2007).

\section{Tingkat Keterbacaan LKS dan Buku Siswa}

Berdasarkan hasil penelitian dapat dihitung rata-rata prosentase tingkat keterbacaan LKS yaitu sebesar 54,8\%, sehingga dapat disimpulkan bahwa materi LKS tepat diterapkan untuk pembelajaran.

Berdasarkan hasil penelitian dapat dihitung rata-rata prosentase tingkat keterbacaan buku siswa yaitu sebesar $54,06 \%$, sehingga dapat diperoleh informasi bahwa materi buku siswa tepat untuk pembelajaran. Menurut BSNP (2006) bahwa informasi yang disajikan dalam buku siswa hendaknya memberikan arti bagi siswa (meaningful), memiliki aspek keterbacaan yang tinggi, menarik dan memikat serta isi bahasanya mampu mengoptimalkan daya pikir siswa.

\section{Tingkat Kesulitan LKS dan Buku Siswa}

Berdasarkan hasil penelitian dapat dihitung rata-rata prosentase tingkat kesulitan LKS yaitu sebesar $0,63 \%$, sehingga dapat diperoleh informasi bahwa tingkat kesulitan LKS sangat rendah atau LKS sangat mudah dipahami.

Berdasarkan hasil penelitian dapat diperoleh dihitung rata-rata prosentase tingkat kesulitan Buku Siswa yaitu sebesar $0,87 \%$, sehingga dapat disimpulkan bahwa tingkat kesulitan Buku Siswa sangat rendah atau Buku Siswa sangat mudah dipahami.

\section{Hasil Uji Coba}

Berdasarkan data hasil pengamatan keterlaksanaan RPP diperoleh informasi bahwa semua fase pembelajaran pada pertemuan I, II, dan III telah terlaksana. Secara umum pada kegiatan pendahuluan, kegiatan inti, dan kegiatan penutup termasuk dalam kriteria baik.

Pertanyaan-pertanyaan essay terbuka yang terdapat pada LKS, Buku Siswa, maupun tugas-tugas yang diberikan kepada siswa dapat memberi manfaat untuk melatihkan keterampilan berpikir kritis dan kreatif. Hal ini didukung oleh Fardah (2012) yang menjelaskan bahwa soal open-ended dapat digunakan untuk melatihkan 
keterampilan berpikir kreatif. Agar pembelajaran guided discovery mencapai tujuan pembelajaran, Carin (1993) menyarankan agar: (1) Membantu siswa memahami tujuan dari kegiatan yang dilakukan; (2) Memeriksa bahwa semua siswa memahami tujuan kegiatan dan prosedur kegiatan yang harus dilakukan; (3) Sebelum kegiatan dilakukan, menjelaskan dahulu cara bekerja yang aman; (4) Mengamati setiap siswa selama melakukan kegiatan; (5) Memberikan waktu yang cukup kepada siswa untuk mengembalikan alat dan bahan yang digunakan; (6) Melakukan diskusi tentang kesimpulan untuk setiap jenis kegiatan.

Pada aspek pengelolaan waktu termasuk dalam kriteria baik. Untuk antusias siswa dan guru termasuk dalam kriteria baik. Guru memiliki peran yang penting dalam pembelajaran Guided Discovery yaitu sebagai fasilitator untuk mengembangkan keterampilan proses siswa dan membangun konsep, oleh karena itu dalam pengelolaan kelas harus sesuai dengan langkah-langkah pembelajaran yang telah disusun. Hal ini dengan sendirinya yang akan membuat siswa aktif, karena menurut Carin (1993) pembelajaran Guided Discovery dapat membuat siswa aktif.

Beberapa hambatan yang dialami selama proses belajar mengajar muncul baik dari faktor siswa, maupun guru. Beberapa hambatan tersebut antara lain: 1) siswa belum pernah melakukan proses pembelajaran dengan menggunakan model pembelajaran Penemuan Terbimbing serta pembelajaran yang melatih keterampilan berpikir kritis dan kreatif, sehingga siswa masih sedikit bingung dan kurang percaya diri baik dalam melakukan kegiatan pembelajaran maupun dalam berpedapat; 2) terdapat kelompok yang kurang aktif selama pembelajaran; dan 3) pada setiap kelompok terdapat 1 atau 2 orang siswa yang terlalu aktif, bahkan cenderung mendominasi ketika kegiatan diskusi.

Beberapa hambatan tersebut diatasi dengan cara pada pertemuan berikutnya diawal, ditengah, dan diakhir pembelajaran guru selalu mengingatkan kembali langkah-langkah kegiatan pembelajaran dengan menggunakan model pembelajaran Penemuan Terbimbing; guru memberikan kesempatan kepada siswa untuk dapat berpikir kritis dan kreatif melalui pertanyaan-pertanyaan terbuka (open questions) yang terdapat di LKS dan Buku Siswa, dan selalu memberikan semangat terhadap hal tersebut. Corebima (2001) menjelaskan bahwa pertanyaan-pertanyaan terbuka (open questions) sangat baik jika dapat diterapkan karena akan menuntut siswa untuk menjawabnya secara logis atau menggunakan penalaran seperti yang termasuk dalam indikator keterampilan berpikir kritis. Hal tersebut sesuai dengan yang dikemukakan Hastuti (2010), bahwa penerapan strategi-strategi dalam Guided Discovery dengan menggunakan LKS bersifat open ended dapat meningkatkan kemampuan berpikir kritis siswa.

Guru rajin mengingatkan siswa agar aktif berpartisipasi aktif baik didalam kelompoknya maupun ketika berdiskusi; guru menjelaskan bahwa keaktifan menjadi salah satu faktor penilaian. Melalui diskusi, siswa dapat mengembangkan kemampuan berpikir kritisnya seperti yang disarankan oleh Meyers (1986), karena dalam kegiatan diskusi dapat menguji kemampuan penalaran logis mereka dalam rangka membentuk karakter pemikir kritis (Fascione, 2010) yaitu: 1) mencari tahu (inguisitive); 2) mencari kebenaran (truth seeking); 3) bersikap sistematis 
(systematic);

4) menganalisis

(analitycal); 5) berpikiran terbuka (open minded); 6) percaya diri dalam bernalar (confident in reasoning); dan bijaksana (judicious). Washton

mengemukakan bahwa untuk kreativitas dalam sains siswa seharusnya diberikan kesempatan antara lain: 1) Untuk bertanya melalui pertanyaan yang bersifat memacu rasa ingin tahu selama setiap guru selesai menerangkan, diskusi, hafalan, atau kegiatan di laboratorium; 2) Untuk lebih banyak membaca buku yang bermutu, karena hal tersebut dapat memacu rasa ingin tahu siswa; 3) Untuk merasa senang untuk memecahkan berbagai masalah melalui pertanyaanpertanyaan; 4) Untuk membuat suatu proposal yang asli tanpa ejekan maupun tertawaan.

Berdasarkan hasil analisis Tes Hasil Belajar Kognitif pada uji coba 2, dapat diperoleh informasi bahwa penerapan pembelajaran dengan menggunakan perangkat pembelajaran yang dikembangkan dapat menuntaskan seluruh Tujuan Pembelajaran aspek kognitif, dengan proporsi jawaban siswa pada uji akhir (posttest) untuk masingmasing tujuan pembelajaran lebih besar daripada Kriteria Ketuntasan Minimal (KKM) $(\geq 0,75)$. Pada uji awal (pretest), dari 14 tujuan pembelajaran seluruhnya tidak tuntas. Pada uji akhir (Posttest), seluruh tujuan pembelajaran telah mencapai ketuntasan. Sensitivitas butir soal dari 16 butir soal seluruhnya berada antara 0,30 - 1,0, hal ini menunjukkan bahwa seluruh butir soal peka terhadap efek-efek pembelajaran. Semakin besar nilai sensitivitas soal menunjukkan bahwa kepekaan butir soal terhadap efek-efek pembelajaran juga semakin besar. Menurut Gronlund (1981), butir soal dikatakan memiliki nilai sensitivitas apabila mempunyai tingkat sensitivitas $\geq$ 0,30 .
Pada uji awal (pretest), seluruh siswa tidak tuntas. Hal ini ditunjukkan dengan rata-rata proporsi jawaban tes sebesar 16,58. Pada uji akhir (posttest), sebanyak 6 siswa tidak tuntas. Hal ini ditunjukkan dengan rata-rata proporsi jawaban tes sebesar 80,70. Ketuntasan klasikal yang dicapai sebesar $80 \%$. Sebanyak 6 dari 30 siswa tidak tuntas pada postest. Pramonoadi (2009) mengemukakan bahwa penerapan pembelajaran Penemuan Terbimbing berpengaruh positif terhadap hasil belajar siswa. Pendapat tersebut didukung oleh Karim (2011) yang mengemukakan bahwa pemahaman konsep dan kemampuan berpikir kritis siswa dengan metode penemuan terbimbing lebih baik dari pada siswa yang mengikuti pembelajaran konvensional. Sebanyak 26 siswa memiliki nilai N-Gain dengan kategori tinggi dan sebanyak 4 siswa memiliki nilai $\mathrm{N}$-Gain dengan kategori sedang. Untuk nilai $\mathrm{N}-$ Gain dari 30 siswa berada pada kriteria sedang dan tinggi. Gain menunjukkan perbedaan penguasaan atau pemahaman konsep siswa sebelum dan setelah diberikan perlakuan. Gain skor ternormalisasi menunjukkan tingkat efektivitas perlakuan daripada perolehan skor $\mathrm{N}$ Gain (Hake, 1999).

Analisis Tes Keterampilan

Berpikir Kritis siswa dilakukan menggunakan analisis Sensitivitas dan nilai N-Gain. Diperoleh informasi bahwa tingkat keterampilan berpikir kritis dari seluruh siswa mengalami peningkatan, dengan peningkatan yang bervariasi. Pada Gambar 1 berikut ini, dapat dikemukakan bahwa secara umum penguasaan indikator keterampilan berpikir kritis siswa meningkat dengan skala tingkat berpikir kritis yang bervariasi setelah melaksanakan pembelajaran dengan menggunakan 
perangkat pembelajaran yang dikembangkan.

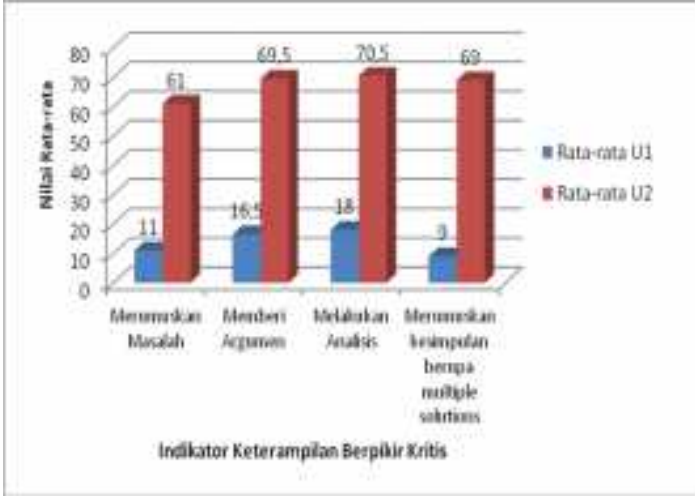

Gambar 1. Penguasaan indikator keterampilan berpikir kritis

Data tersebut menunjukkan bahwa pembelajaran dengan menggunakan Penemuan Terbimbing memiliki beberapa keuntungan, diantaranya dapat memacu rasa ingin tahu siswa, memotivasi mereka untuk melanjutkan pekerjaannya sehingga mereka menemukan jawabannya, memecahkan masalah secara mandiri dan keterampilan berpikir kritis (Nur dan Wikandari, 2000). Hal ini sejalan dengan yang dikemukakan oleh Abruscato (1992) bahwa apabila kita menggunakan aktivitas sains yang menggunakan proses discovery, siswa akan memiliki banyak kesempatan untuk menerapkan keterampilan berpikir kritis mereka.

Berdasarkan analisis data didapatkan informasi bahwa dari 8 butir soal tes keterampilan berpikir kritis, seluruhnya memiliki indeks sensitivitas $\geq$ 0,30 . Kriteria yang dipakai untuk menyatakan bahwa setiap butir peka atau sensitif terhadap efek-efek pembelajaran adalah mempunyai nilai sensitivitas $(\mathrm{S}) \geq$ 0,30 . Indeks sensitivitas butir soal yang efektif terdapat antara 0,00 dan 1,00 dan nilai positif yang semakin besar menunjukkan bahwa kepekaan butir soal terhadap efek-efek pembelajaran juga semakin besar. Menurut Gronlund (1981) suatu butir soal dikatakan sensitif bila harga sensitivitasnya lebih dari 0 atau berharga positif. Semakin besar harga sensitivitasnya maka makin besar kepekaan butir soal terhadap efek pembelajaran. Oleh karena itu butir-butir soal keterampilan berpikir kritis yang digunakan pada pretest dan posttest dapat digunakan untuk mengukur efekefek pembelajaran.

Nilai N-Gain dari 30 siswa berada pada kriteria sedang dan tinggi. Sebanyak 18 siswa memiliki nilai NGain dengan kategori tinggi dan sebanyak 12 siswa memiliki nilai $\mathrm{N}$-Gain dengan kategori sedang. Gain menunjukkan perbedaan penguasaan atau pemahaman konsep siswa sebelum dan setelah diberikan perlakuan. Gain skor ternormalisasi menunjukkan tingkat efektivitas perlakuan daripada perolehan skor N-Gain (Hake, 1999). Hasil tersebut dapat menjelaskan bahwa pembelajaran dengan menggunakan pendekatan Guided Discovery dapat dengan efektif melatihkan keterampilan berpikir kritis. Akinbobola (2010) merekomendasikan bahwa guru seharusnya berusaha keras untuk menerapkan pendekatan konstruktivisme melalui Guided Discovery dengan harapan agar mengarahkan siswa pada aktivitas problem solving, pembelajaran mandiri, belajar berpikir kritis, dan berpikir kreatif, daripada sekedar mengingat.

Melalui pembelajaran Guded Discovery siswa diajak untuk berpikir menemukan sendiri konsep-konsep penting dalam pembelajaran. Menurut Berlyne (1965) dalam Nur dan Wikandari (2008), bahwa metode ini memacu keinginan hendak tahu siswa, memotivasi mereka untuk melanjutkan pekerjaannya hingga mereka menemukan jawabannya. Siswa juga 
belajar memecahkan masalah secara mandiri dan keterampilan berpikir kritis karena mereka harus selalu menganalisis dan menangani informasi.

Berdasarkan hasil analisis data dapat diperoleh informasi bahwa terdapat peningkatan rata-rata skor post test pada Tes Kreativitas Verbal, dan peningkatan skala tingkat berpikir kreatif siswa. Keterampilan berpikir kreatif siswa dianalisis dengan mengacu pada 5 indikator yaitu: kelancaran, kelenturan, orisinalitas, elaborasi, dan menilai.

Berdasarkan Gambar 2 berikut ini, dapat dikemukakan bahwa secara umum penguasaan indikator keterampilan berpikir kreatif siswa meningkat setelah melaksanakan pembelajaran dengan menggunakan perangkat pembelajaran yang dikembangkan. Munandar (1999) mengemukakan bahwa mengajar dengan discovery selain berkaitan dengan penemuan juga bisa meningkatkan kemampuan berpikir kreatif.

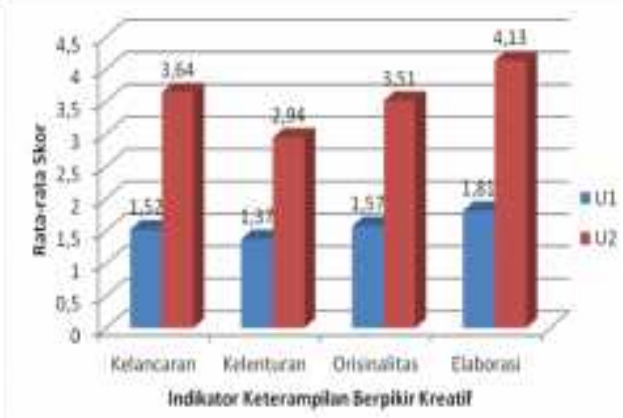

Gambar 2. Penguasaan Indikator Keterampilan Berpikir Kreatif

Berdasarkan analisis data dapat diketahui bahwa dari 30 siswa seluruhnya mengalami peningkatan kriteria hasil tes kreativitas produk. Dengan terampil memecahkan masalah, maka siswa telah mencapai hasil belajar yang paling tinggi (Gagne, 1978). De Cecco (1977) dalam Ibrahim (1985) mengatakan bahwa pemecahan masalah (problem solving) merupakan istilah lain untuk kreativitas atau berpikir kreatif. Hal ini menunjukkan eratnya hubungan antara kreativitas dan pemecahan masalah. Pendapat ini diperkuat oleh Guilford dalam Munandar (2009) bahwa kreativitas atau berpikir kreatif sebagai kemampuan untuk melihat bermacammacam kemungkinan penyelesaian terhadap suatu masalah.

Berdasarkan hasil analisis, dapat dijelaskan bahwa kriteria kemampuan berpikir kreatif siswa yang mengacu pada angket Skala Sikap Kreatif mengalami peningkatan, dengan tingkatan kriteria kemampuan berpikir kreatif yang bervariasi. Garner (2012) yang mengungkapkan bahwa ketika kita memerlukan jalan keluar untuk menyelesaikan suatu masalah yang sulit dipecahkan, kita butuh untuk lebih kreatif serta membutuhkan berpikir dan menemukan solusi, mengembangkan pemikiran baru dan solusi baru, dengan menggunakan otak kanan. Glaser dalam Carin (1993) menjelaskan bahwa pembelajaran Penemuan Terbimbing sangat membantu perkembangan pemecahan masalah, kreativitas, dan belajar independen. Pendapat tersebut didukung oleh hasil penelitian Rohim (2012), bahwa pembelajaran dengan menggunakan model Discovery terbimbing dapat meningkatkan kemampuan berpikir kreatif siswa.

Secara keseluruhan, siswa memberikan respon positif terhadap pembelajaran. Respon positif ini menunjukkan bahwa siswa antusias dengan pembelajaran yang disajikan. Hal ini dapat memotivasi siswa untuk meningkatkan perhatian dan membuat mereka terlibat dalam pengalaman pembelajaran yang menyenangkan dan bermakna (Nur, 2008). Antusiasme siswa yang tinggi ini didukung oleh Kardi (1997), yang mengemukakan bahwa Penemuan Terbimbing merupakan model 
pembelajaran yang memberi kesempatan dan menuntut siswa terlibat secara aktif dalam mencapai tujuan pembelajaran.

\section{Kesimpulan dan Saran}

Berdasarkan hasil validasi dan implementasi perangkat pembelajaran yang dikembangkan di lapangan, dapat disimpulkan bahwa perangkat pembelajaran berorientasi Guided Discovery yang dikembangkan valid, praktis, efektif, dan dapat meningkatkan keterampilan berpikir kritis dan kreatif siswa, serta dapat mencapai ketuntasan hasil belajar siswa.

Berdasarkan penelitian yang telah dilakukan dan hasil yang diperoleh, disarankan beberapa hal yaitu (a) model pembelajaran Penemuan Terbimbing (Guided Discovery) disarankan untuk dapat diterapkan pada materi pembelajaran biologi yang lain dan (b) berpikir kritis dan kreatif harus sering dilatihkan dalam pembelajaran.

\section{Daftar Pustaka}

Abruscato, J. 1992. Teaching Children Science, third edition. New York: Allyn \& Bacon A Division of Simon \& Schuster, Inc.

Akinbobola, A.O. and Afolabi, F. 2010. "Constructivist Practices through Guided Discovery Approach: The Effect on Students' Cognitive Achievement in Nigerian Senior Secondary School Physics" Eurasian J.Phys. Chem.Educ. Vol 2 No 1.

Arends, R. 2007. Learning to Teach: Seven Edition. New York: Mc Graw-Hill Companies.

Arikunto, S. 2006. Prosedur Penelitian, Suatu Pendekatan Praktis. Jakarta: Rineka Cipta.
Carin, A.A. 1993. Teaching Science Through Discovery Seventh Edition. New York: Macmillan Publishing Company.

Corebima, A.D. 2001. "Pola Pengembangan Lembar PBMP (TEQ) dalam Pembelajaran IPABiologi". Makalah disajikan pada Pelatihan dan Lokakarya PBMP di Universitas Negeri Malang, Malang.

Eggen, P.D. and Kauchak, D.P. 1996. Strategies and Models for Teacher, Teaching Content and Thinking Skills. New York: Allyn \& Bacon, A Simon Schuster Company.

Grounlund, N.E. 1981. Measurement and Evaluation in Teaching $4^{\text {th }}$ edition. New YorkL Macmillan Pub.Co.

Ibrahim, M. 2008. Model Pembelajaran Inovatif IPA Melalui Pemaknaan.. Jakarta: Depdiknas BalitbangPuslitjaknov.

Karim, A. 2011. "Penerapan Metode Penemuan Terbimbing dalam Pembelajaran Matematika untuk Meningkatkan Pemahaman Konsep dan Kemampuan Berpikir Kritis Siswa Sekolah Dasar". Jurnal Universitas Pendidikan Indonesia Edisi Khusus. No 1.

Munandar, U. 2009. Pengembangan Kreativitas Anak Berbakat. Jakarta: Rineka Cipta.

Mustami, M. K. 2007. "Pengaruh Model Pembelajaran Synectics yang Dipandu Mind Maps dan Kooperatif STAD terhadap Kemampuan Berpikir Kreatif, Sikap Kreatif, dan Penguasaan Materi Biologi Siswa SMP Kota Makassar". Disertasi Doktor, Universitas Negeri Malang. 